\title{
Identification of a novel nutrient-deprivation- induced Sinorhizobium meliloti gene (hmgA) involved in the degradation of tyrosine
}

\author{
Anne Milcamps ${ }^{1,2}$ and Frans J. de Bruijn ${ }^{1,2,3}$
}

NSF Center for Microbial Ecology 1 , MSU-DOE Plant Research Laboratory², and Department of

Microbiology 3 , Michigan State University, East Lansing, MI 48824, USA
Author for correspondence: Frans J. de Bruijn (MSU-DOE Plant Research Laboratory). Fax: +1 5173559614. e-mail : debruijn@pilot.msu.edu

\begin{abstract}
Sinorhizobium meliloti strain N4 carries a Tn5/uxAB insertion in a gene which is induced by nitrogen and carbon deprivation as well as in the presence of tyrosine. The Tn5/uxAB-tagged locus was found to share significant similarity with the human hmgA gene and the corresponding Aspergillus nidulans gene, encoding the enzyme homogentisate dioxygenase, which is involved in the degradation of tyrosine. Extended DNA sequence analysis of the tagged locus revealed the presence of several ORFs, including one encoding a polypeptide sharing a high degree of similarity with human and fungal maleylacetoacetate isomerases. Strain N4 was found to be unable to use tyrosine as carbon source, to lack homogentisate dioxygenase activity, to produce a melanin-like pigment and to be affected in stationary-phase survival. This is believed to be the first report of a hmgA-homologous gene in bacteria.
\end{abstract}

Keywords: Rhizobium, starvation, homogentisate dioxygenase, maleylacetoacetate isomerase, glutathione $S$-transferase

\section{INTRODUCTION}

Bacteria often encounter severe stress conditions such as nutrient limitation, temperature shifts, $\mathrm{pH}$ variability, oxidative stress and osmotic stress in their natural environment (Foster \& Spector, 1995; Graham, 1991; Moriarty \& Bell, 1993). Coping with and surviving these adverse conditions requires numerous physiological changes and morphological adaptations. Much of our knowledge regarding bacterial responses to nutrient limitation comes from studies on Bacillus subtilis, Salmonella typhimurium and marine Vibrio species (Hecker et al., 1996; Spector et al., 1993; Ostling et al., 1993). However, Escherichia coli has served as a model system and its responses to starvation or entry into stationary phase have been studied in detail. Several morphological effects have been observed, such as the generation of smaller and sphere-shaped cells (Lange \& Hengge-Aronis, 1991). Numerous physiological changes have been described that occur when $E$. coli cells enter stationary phase. Storage compounds such as glycogen are synthesized (Okita et al., 1981). Proteins are degraded at a higher rate to provide the starving cell with

\footnotetext{
Abbreviations: GST, glutathione S-transferase; RLU, relative light units. The GenBank accession number for the sequence reported in this paper is Af109131.
}

amino acids for the synthesis of new proteins and to remove abnormal proteins resulting from cellular breakdown (Mandelstam, 1963; Li et al., 1994). RNase activity in stationary-phase cells increases (Mandelstam, 1963) and nutrient-scavenging capacity is enhanced by increased synthesis or production of alternative substrate-capturing or metabolic enzymes, and specific transport systems (for reviews, see Matin et al., 1989; Kolter et al., 1993).

Many starvation-induced proteins have been identified by means of two-dimensional-PAGE. Nystrom (1994) and Matin (1991) have shown that at least 70 proteins (Pex and Cst) are induced by nitrogen, phosphate or carbon limitation. Lomovskaya et al. (1994) cloned one of the cAMP-independent starvation-induced loci (the pexB gene) via reverse genetics but most of the genes encoding these proteins have not been characterized in detail. Genes that have been investigated include the energy-metabolism genes bya and $c b d A B-a p p A$ (Atlung et al., 1997), the peptide-transport gene cst $A$ (Schultz $\&$ Matin, 1991), the ugp operon encoding the uptake of phosphate compounds (Kasahara et al., 1991), the carbon-starvation-induced csi loci (Weichart et al.,1993) and the carbon-starvation-induced csi (slp) loci that encode secreted products (Alexander et al., 1993; Alexander \& St John, 1994). Several loci with a (putative) regulatory function have been identified, 
including $r p o S$ encoding a stationary-phase-related sigma factor, which controls the expression of several stationary-phase-induced genes (Lange \& HenggeAronis, 1991; Hengge-Aronis, 1993), uspA, encoding the universal stress protein (Nystrom \& Neidhart, 1994), the $s s p A$ gene encoding a stringent starvation protein (Williams et al., 1994), the cspA cold-shock gene analogue $c s p D$ (Yamanaka \& Inouye, 1997), the phosphate-starvation-induced $c b p A$ locus encoding a DNA-binding protein (Yamashino et al., 1994) and the him and hip genes encoding integration host factor (IHF) (Nystrom, 1995).

In contrast to what is known in E. coli, little information is available about the physiological response of soil bacteria to nutrient deprivation or slow growth rate conditions (for reviews, see Roszak \& Colwell, 1987; van Elsas \& van Overbeek, 1993). However, their ability to cope with nutritional and other environmental stresses is of vital importance for their survival, persistence and competitiveness in the soil. Soil is a harsh, oligotrophic environment (Williams, 1985). Growth substrates are scarcely available because of a paucity of organic matter, the insolubility of organic substrates, their recalcitrant nature (i.e. humus or lignin) and limited microbial access to these nutrients. Therefore, in the soil, bacterial growth is very slow and periods of non-growth occur frequently. The rhizosphere soil is more advantageous for growth of soil microbes, due to the presence of root exudates which provide readily accessible nutrients. However, even in the rhizosphere, bacterial growth and activity are generally limited to the short periods during which such exudates are available (Lynch \& Whipps, 1990).

Recently, several research groups have started to investigate the response of soil micro-organisms to nutrient-limiting conditions, either in culture or in the soil habitat, and have identified a number of nutrientlimitation-induced genes. For example, Pseudomonas fluorescens has been mutagenized with a $\operatorname{Tn} 5 \operatorname{lu} x A B$ reporter gene transposon, resulting in the isolation of loci induced by deprivation for nitrogen and phosphate (Kragelund et al., 1995). One of the phosphatedeprivation-induced gene fusions has been used as a. reporter system to assay phosphate availability in the barley rhizosphere (Kragelund et al., 1997). In Pseudomonas putida, a gene involved in carbon starvation survival has been identified by mini-Tn 5 mutagenesis (Kim et al., 1995). Morphological and physiological changes have been documented for Rhizobium leguminosarum bv. phaseoli in stationary growth phase (Thorne \& Williams, 1997), showing a general response (decreased protein, DNA and RNA synthesis) similar to E. coli. The deprived cells also exhibited crossprotection against other stresses. In addition, Uhde et al . (1997) have described the isolation of Sinorbizobium meliloti mutants affected in stationary growth phase survival and carrying the transposon insertion in a gene encoding an ABC-type transporter, genes for cytcchrome synthesis or genes for amino acid metabolism.

We have focused our investigations on strain 1021 of the common soil microbe $S$. meliloti, the nitrogen-fixing symbiont of alfalfa, for which an extensive system of genetic analysis is available. Using Tn 5 lux $A B$ (Wolk et al., 1991), we have isolated $33 \mathrm{~S}$. meliloti strains with Tn5luxAB gene fusions induced by either nitrogen or carbon deprivation or both (Milcamps et al., 1998). Here, we report the characterization of the $\operatorname{Tn} 5 \operatorname{lu} x A B$ tagged locus in one of these strains (N4), identifying a novel bacterial gene involved in tyrosine degradation.

\section{METHODS}

Strains and plasmids. The following strains were used: Sinorbizobium meliloti strain 1021 (Meade et al., 1982) and Escherichia coli DH5 $\alpha$ (Hanahan, 1983). S. meliloti strain 1021 is the reference strain. S. meliloti strains N1, N4, N12 and N110 were obtained by Tn5-1063 mutagenesis of strain 1021 and carry $\operatorname{Tn} 5 \operatorname{lu} x A B$ reporter gene fusions that are inducible under conditions of nitrogen deprivation (Milcamps et al., 1998). The following plasmids were used: pRK2013 [ColE1 replicon, $\mathrm{Tra}^{+}, \mathrm{Km}^{\mathrm{r}}$ (Ditta et al., 1980)], pPH1JI [IncP, Tra ${ }^{+}$, $\mathrm{Cm}^{\mathrm{r}} \mathrm{Sm}^{\mathrm{r}} \mathrm{Sp}^{\mathrm{r}} \mathrm{Gm}^{\mathrm{r}}$ (Hirsch \& Beringer, 1984)] ; pLAFR1 [broad host range, IncP, $\mathrm{Mob}^{+} \mathrm{Tra}^{-}, \mathrm{Tc}^{r}$ (Friedman et al., 1982)]; pBluescript II SK [Ap ${ }^{r}$, obtained from Stratagene]. pN4Eco and $\mathrm{pN} 4 \mathrm{Cla}$ are plasmids recovered from strain $\mathrm{N} 4$ and carry the Tn5-1063 with flanking DNA on a EcoRI fragment and Clal fragment respectively ( $\mathrm{Km}^{\mathrm{r}}$, this work). pLAFRN4Eco is pN4Eco cloned into pLAFR1 (this work).

Growth media and conditions. E. coli strains were grown at $37^{\circ} \mathrm{C}$ on LB medium (Silhavy et al., 1984), supplemented with desired antibiotics at the following final concentrations: $\mathrm{Km}$ $25 \mu \mathrm{g} \mathrm{ml}^{-1}$, Tc $10 \mu \mathrm{g} \mathrm{ml}^{-1}$, Sp $50 \mu \mathrm{g} \mathrm{ml}^{-1}$. S. meliloti strains were grown at $28^{\circ} \mathrm{C}$ on TY medium (Beringer, 1974) or GTS medium, supplemented with the appropriate antibiotics $(\mathrm{Sm}$ for S. meliloti 1021 at $100 \mu \mathrm{g} \mathrm{ml}^{-1} ; \mathrm{Km}$ for Tn5luxAB-bearing mutant strains at a final concentration of $\left.200 \mu \mathrm{g} \mathrm{ml}^{-1}\right)$. The composition of basic GTS medium is (per litre) : $0 \cdot 1 \mathrm{~g} \mathrm{~K}_{2} \mathrm{HPO}_{4}$; $1 \mathrm{~g} \mathrm{NaCl} ; 3 \mathrm{~g}$ Tris; $246 \mathrm{mg} \mathrm{MgSO}_{4} .7 \mathrm{H}_{2} \mathrm{O} ; 11 \mathrm{mg} \mathrm{CaCl}{ }_{2}$; $0.27 \mathrm{mg} \quad \mathrm{FeCl}_{3} \cdot 6 \mathrm{H}_{2} \mathrm{O} ; 0.242 \mathrm{mg} \quad \mathrm{Na}_{2} \mathrm{MoO}_{4} \cdot 2 \mathrm{H}_{2} \mathrm{O} ; 3 \mathrm{mg}$ $\mathrm{H}_{3} \mathrm{BO}_{3} ; 2.23 \mathrm{mg} \mathrm{MnSO}_{4} .4 \mathrm{H}_{2} \mathrm{O} ; 0.287 \mathrm{mg} \mathrm{ZnSO}_{4} .7 \mathrm{H}_{2} \mathrm{O}$; $0.125 \mathrm{mg} \mathrm{CuSO} \mathrm{O}_{4} .5 \mathrm{H}_{2} \mathrm{O} ; 0.065 \mathrm{mg} \mathrm{CoCl} 2 ; 2 \mathrm{mg}$ biotin (Kiss et al., 1979). The carbon source in GTS medium was succinate $(0.27 \%)$ and glucose $(0.2 \%)$; the nitrogen source was $\left(\mathrm{NH}_{4}\right)_{2} \mathrm{SO}_{4}(0.2 \%)$, unless specified otherwise. GTS-N is GTS medium devoid of all nitrogen sources; GTS-C is GTS medium devoid of all carbon sources. Phenylalanine, tryptophan or tyrosine was added to basic GTS medium as carbon or nitrogen source at a final concentration of $0 \cdot 2 \%$. When supplemented to GTS or GTS-N, these amino acids were used at a final concentration of $0.02 \%$ or $0.2 \%$.

DNA manipulations. Plasmid DNA for restriction analyses was isolated using an alkaline lysis method according to Sambrook et al. (1989). Plasmid DNA for sequencing was isolated with a Qiagen kit. Hybridization was performed as described by Amersham, using the non-radioactive DNAlabelling and detection kit of Boehringer Mannheim.

Plasmid transfer. Plasmids were introduced into host cells by transformation $\left(\mathrm{CaCl}_{2}\right.$ method) or via triparental conjugation (Sambrook et al., 1989; Ditta et al., 1980; de Bruijn \& Rossbach, 1994).

DNA sequence analysis. Double-stranded DNA sequence analysis of fragments subcloned into Bluescript vectors was performed using standard primers and primer walking approaches. DNA sequencing was carried out at the DNA Sequencing Facility at Michigan State University and the 
Biotech Institute at Yale University (CT, USA). Analysis of the data obtained was carried out using the Sequencher program (Gene Codes Corporation). Codon preference profiles were determined with the CodonUse 3.1 program (C. Halling, University of Chicago, Chicago, IL, USA). Similarity searches were carried out using the BLAST program (Altschul et al., 1990). Alignments of deduced amino acid sequences were obtained using the PILEUP program and similarity values were computed with the BESTFIT program (Genetics Computer Group, Madison, WI, USA).

Measurements of luciferase activity. Luciferase activity in strain N4 was monitored using a Hamamatsu Photonic System model C1966-20 (Photonic Microscopy) coupled to a Nikon $35 \mathrm{~mm}$ f 2.0 macro lens, or a luminometer (Lumat BB9501; Wallace Inc.).

For measurements of luciferase activity of colonies on Petri dishes, an exponentially growing culture was spotted on a filter, placed on GTS medium. The Petri dishes with filters were incubated for $36 \mathrm{~h}$ at $28^{\circ} \mathrm{C}$. Subsequently, the filters were transferred to GTS medium (control) and GTS-N, GTS-C or GTS supplemented with different amino acids at a concentration of $0.02 \%$, as indicated in the text. The Petri dishes were incubated at $28^{\circ} \mathrm{C}$ for $6-24 \mathrm{~h}$ and luciferase activity was analysed with the Hamamatsu photonic camera. For this purpose, $50 \mu \mathrm{ln}$-decyl aldehyde (substrate for luciferase; Sigma) was spread on a glass Petri dish cover, which was subsequently placed over the Petri dish carrying the filter. After 60 s of exposure to the aldehyde, the Petri dish with filter was placed under the camera and photons were counted for $1 \mathrm{~min}$, as described by Wolk et al. (1991).

For measurements of luciferase activity of cultures, an overnight culture, grown in GTS, was diluted in fresh medium and grown to exponential phase. The cells were harvested by centrifugation (rotor and tubes at room temperature) and resuspended in regular GTS medium or modified GTS medium as indicated in the text and figure legends. The cultures were further incubated at $28^{\circ} \mathrm{C}$, and luciferase activity and cell density were measured at regular intervals. Quantitative measurements were carried out using a luminometer. Culture samples $(10 \mu \mathrm{l})$ were mixed with $100 \mu \mathrm{l}$ of a $2 \%$ BSA solution in $\mathrm{H}_{2} \mathrm{O}$ (albumin bovine $98-99 \%$; Sigma), containing $0 \cdot 2 \% \mathrm{n}$ decyl aldehyde, vortexed for $30 \mathrm{~s}$ and immediately analysed with the luminometer. Photons were counted for $1 \mathrm{~min}$ and data were recorded as relative light units (RLU). Luminescence of GTS medium without cells was used for baseline subtraction. For measurements of luciferase activity in carbondeprived cells, $100 \mu \mathrm{l}$ of cells and $100 \mu \mathrm{l}$ of regular GTS medium were vortexed for $10 \mathrm{~s}$, in the presence of FMN $(20 \mu \mathrm{M}$ final). This mixture was incubated at room temperature for $10 \mathrm{~min}$, and a $10 \mu \mathrm{l}$ aliquot was used for photon counting, as described above. GTS was added to provide the carbon-deprived cells with an energy source to reduce FMN to FMNH, which is a required cofactor for the luciferase reaction. It should be noted that quantitative variation in luminescence of the same fusion under the same induction conditions in different experiments is often observed. Therefore, data collected in separate experiments were not compared in a quantitative fashion.

Homogentisate dioxygenase assay. Homogentisate dioxygenase activity was measured by spectrophotometric determination $\left(A_{330}\right)$ of the formation of maleylacetoacetate (Edwards \& Knox, 1955). Exponentially growing cultures of strains 1021 and N4 were centrifuged, and the cells were washed and resuspended in either induction medium (GTS-N supplemented with tyrosine) or regular GTS medium. The assay was carried out after 2 and $4 \mathrm{~h}$ incubation at $28^{\circ} \mathrm{C}$. The cells were collected by centrifugation, concentrated 10-fold in $100 \mathrm{mM}$ potassium phosphate buffer, $\mathrm{pH} 7 \cdot 0$, and lysed by sonication ( $2 \mathrm{~min}$ at $50 \%$ power; TSD-375 Sonic Disruptor; Tekmar). The extract was clarified by centrifugation and aliquots were used for the enzyme assays in reaction mixtures containing, in a final volume of $1 \mathrm{ml}, 100 \mathrm{mM}$ potassium phosphate buffer $\mathrm{pH} 7 \cdot 0,2 \mathrm{mM}$ ascorbate, $50 \mu \mathrm{M} \mathrm{FeSO}$, $250 \mu \mathrm{M}$ homogentisate and $50 \mu \mathrm{l}$ extract (corresponding to $50-75 \mu \mathrm{g}$ protein). Protein concentration was determined with the Bio-Rad protein assay.

Growth and survival in stationary growth phase. Strains 1021 and N4 were cultured in GTS medium in $250 \mathrm{ml}$ flasks and incubated with shaking at $28^{\circ} \mathrm{C}$ for 3 weeks. Viable cells of each culture were counted at regular time intervals by plating a dilution series of each culture on TY. The experiment was performed in triplicate.

Nodulation experiments. Alfalfa (Medicago sativa) seeds were sterilized by soaking in $95 \%$ ethanol for $10 \mathrm{~min}$, followed by $3 \mathrm{~min}$ in $3 \%$ peroxide (freshly prepared) and rinsed several times with sterile $\mathrm{H}_{2} \mathrm{O}$. Seeds were germinated on water agar $(1.2 \%$ agar $)$. Two-day-old seedlings were inoculated with a washed, exponentially growing culture of either strain 1021 or strain N4. The plants were grown in tubes containing $20 \mathrm{ml}$ sterile nitrogen-free $\mathrm{B}+\mathrm{D}$ liquid medium (Broughton \& Dilworth, 1971), incubated in a growth chamber (16 h light, $28^{\circ} \mathrm{C}$ ) for 6 weeks and analysed for nodulation and nitrogen fixation. Acetylene reduction assays were carried out by capping the tubes, containing individual plants, with rubber seal stoppers, injecting acetylene to a final concentration of $10 \%$ of the gas phase and determining ethylene production after 1-3 h, using a Varian (model 3700 ) gas chromatograph.

\section{RESULTS}

\section{Cloning of the $\mathrm{n} 4$ locus and recreation of the Tn5luxAB insertion mutant}

Mutant strain N4 was obtained by screening a $\operatorname{Tn} 5 \operatorname{lux} A B$ insertion bank of $S$. meliloti strain 1021 for strains displaying luciferase activity under nitrogendeprivation conditions (Milcamps et al., 1998). Southern blot analysis of restricted genomic DNA of strain N4, probed with a DNA fragment carrying $\operatorname{Tn} 5 \operatorname{lu} x A B$, showed that this strain contained a single transposon insertion (Milcamps et al., 1998). The tagged locus of strain N4 was excised as an EcoRI or ClaI fragment, selfligated and introduced into $E$. coli as a replicating plasmid ( $\mathrm{pN} 4 \mathrm{Eco}$ and $\mathrm{pN} 4 \mathrm{Cla}$ respectively) due to the oriV within the Tn5luxAB (Wolk et al., 1991). The pN4Eco plasmid was also cointegrated into the broadhost-range vector pLAFR1 (pLAFRN4). pLAFRN4 was subsequently introduced into $S$. meliloti strain 1021 via conjugation, and the wild-type locus was replaced with the tagged locus of strain N4, as described by Ruvkun \& Ausubel (1981). The reconstructed mutant strain (N4R) was examined for luciferase activity and other phenotypic traits (see below) under nitrogen-deprivation conditions, and was found to have an identical phenotype to that of the original N4 mutant strain; this suggested that the original $\operatorname{Tn} \ln x A B$ insertion was indeed responsible for the observed phenotypic traits. The Tn5luxAB-tagged locus of strain N4 will be referred to in the text as the $\mathrm{n} 4$ locus and the chimeric $\operatorname{Tn} 5 \operatorname{lux} A B$ fusion as the $\mathrm{n} 4$ gene fusion. 

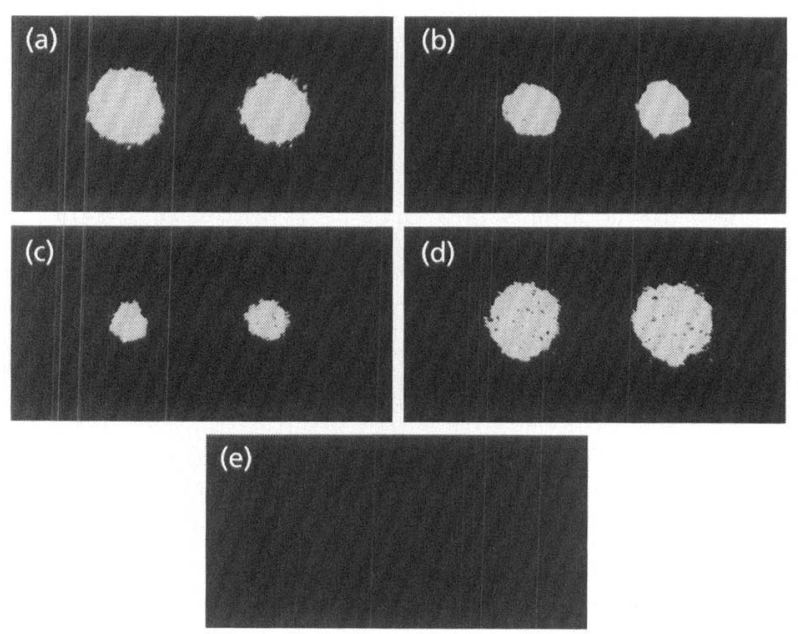

Fig. 1. Luciferase activity of strain N4, grown on solid medium, was visualized with a photonic camera, under the following conditions: (a) nitrogen deprivation; (b) carbon deprivation; (c) TY medium; (d) GTS medium supplemented with tyrosine, (e) GTS medium (control). Two colonies are shown for each treatment.

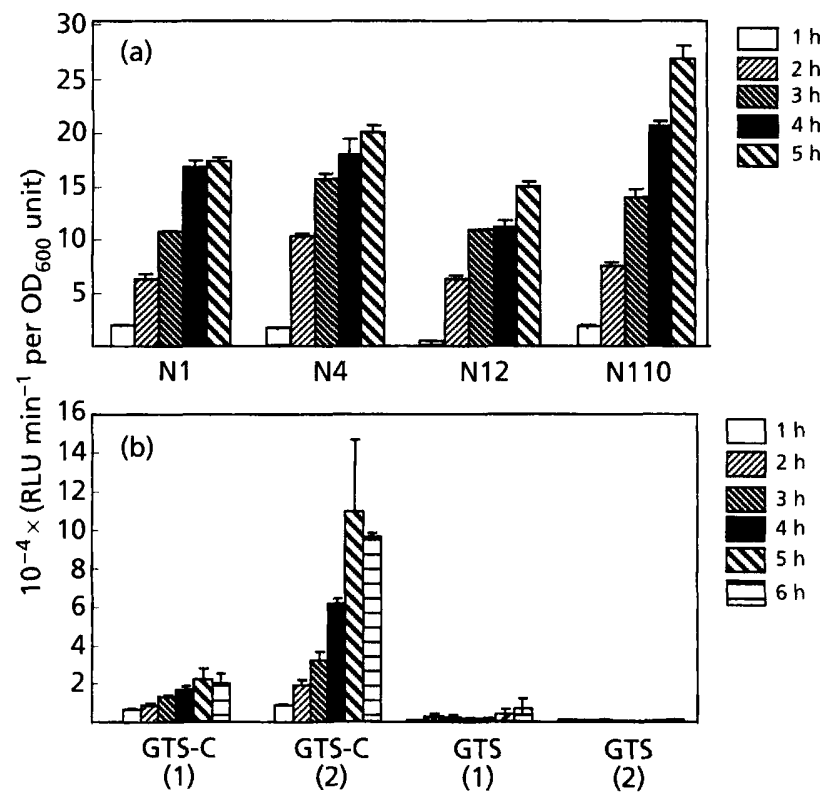

Fig. 2. Luciferase activity of strain N4. (a) Luciferase activity of strain N4 in comparison with strains N1, N12 and N110 (see text for details), measured in nitrogen-free medium. Luciferase activity was determined at $1 \mathrm{~h}$ intervals, up to $5 \mathrm{~h}$. (b) Luciferase activity of strain N4 measured in carbon-free medium (GTS-C) and regular minimal medium (GTS). Luciferase activity was assayed (1) without and (2) with addition of GTS and FMN. The results are means of three independent determinations, \pm SE.

\section{Luciferase activity of strain N4}

Strain N4 was analysed for its luminescence under different conditions, using a photonic camera (see Methods) (Fig. 1). Induction of the $\mathrm{n} 4$ gene fusion harboured by strain $\mathrm{N} 4$, resulting in luciferase expression, was observed under nitrogen-deprivation (GTS-N) and carbon-deprivation (GTS-C) conditions but, surprisingly, also on rich medium (TY) (Fig. 1). Quantitative measurements of the luciferase activity were performed on broth cultures of strain N4. Nitrogen-deprivation conditions were created by resuspending exponentially growing cells in nitrogenfree medium (GTS-N). The influence of the growth phase of the culture on luciferase activity was first determined. For this purpose, a culture of strain N4 was sampled as the $\mathrm{OD}_{600}$ increased from 0.2 to 1.5 , and the cells were analysed for luciferase activity (see Methods). Luminescence was observed as long as cells were in the exponential growth phase (up to $\mathrm{OD}_{600} 1$ ). Cells in the stationary growth phase, however, did not respond well to transfer to deprivation medium and showed a decline in luciferase activity (data not shown). This decline is likely to be due to a lack of energy $\left(\mathrm{FMNH}_{2}\right)$ in stationary-phase cells, which produce less reducing power (Siegele \& Kolter, 1992). It should be pointed out that cells resuspended in regular GTS medium keep growing; cells in GTS-N medium are retarded in growth and cells in GTS-C medium stop growing immediately after resuspension.

Measurement of luciferase activity over time showed that the $\mathrm{n} 4$ gene fusion was induced after $1 \mathrm{~h}$ of nitrogen deprivation (Fig. 2a). Luminescence increased over time but levelled off after $8-10 \mathrm{~h}$, as cells started to reach the late exponential phase (data not shown). Therefore, in subsequent experiments, an induction time of $4 \mathrm{~h}$ was used.

When strain $\mathrm{N} 4$ was analysed for luciferase activity in comparison to strains N1, N12 and N110 (carrying lu $x A B$ fusions in loci different from the $\mathrm{n} 4$ locus but also induced by nitrogen deprivation), a similar level of activity was found (Fig. 2a). Moreover, the temporal pattern of nitrogen deprivation induction did not differ between these strains, suggesting that the observed expression pattern (intensity and temporal activity) was shared by all four nitrogen-deprivation-induced fusions. Incubation of strain N4 in carbon free medium (GTS-C) resulted in a very low level of luciferase activity (Fig. 2 b). As pointed out above, this is likely to be caused by the lack of $\mathrm{FMNH}_{2}$ (Meighen \& Dunlap, 1993), which cannot be generated by bacterial cells in the absence of a suitable carbon source. Luciferase activity of the $n 4$ gene fusion could indeed be increased by briefly providing the carbon-deprived cells of strain $\mathrm{N} 4$ with an energy source shortly before the luciferase assay (see Methods; Fig. 2b).

$\left(\mathrm{NH}_{4}\right)_{2} \mathrm{SO}_{4}$ was found to inhibit the luciferase activity in strain $\mathrm{N} 4$ at a minimum concentration of $2 \mathrm{mM}$. Therefore, concentrations below this level of available nitrogen were considered as deprivation conditions in this study. The $\mathrm{n} 4$ gene fusion was found to be induced on rich medium (TY), but to a lesser degree' than on nitrogen-free medium. To examine if a particular component of TY medium induced the expression of the $\mathrm{n} 4$ gene fusion, luciferase measurements were carried 

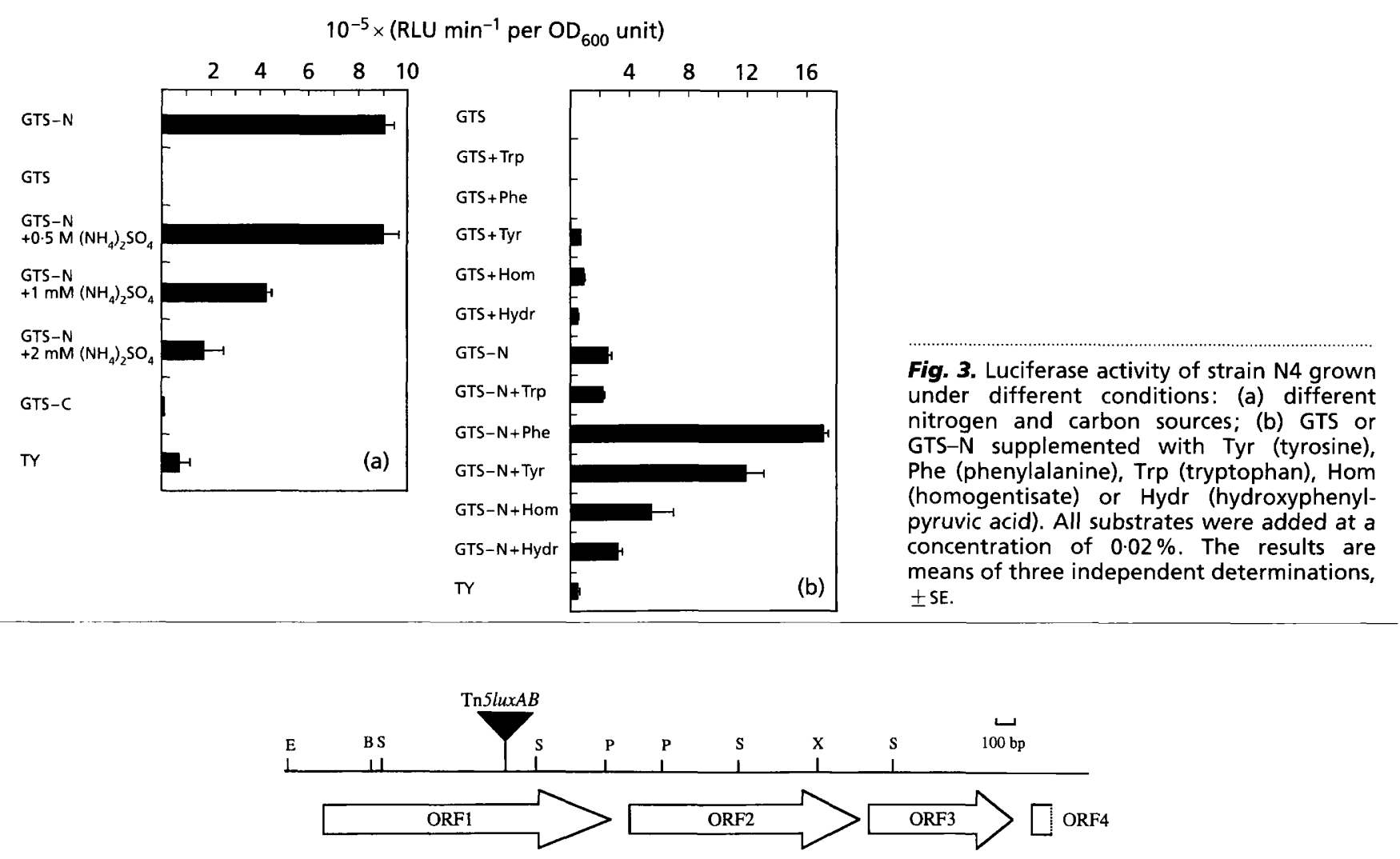

\begin{tabular}{|c|c|}
\hline $\begin{array}{c}\text { ORF } \\
1\end{array}$ & \begin{tabular}{l}
\multicolumn{1}{c}{ Function } \\
Homogentisate dioxygenase \\
Homogentisate dioxygenase \\
Homogentisate dioxygenase \\
Unknown
\end{tabular} \\
\hline 2 & Unknown \\
\hline 3 & $\begin{array}{l}\text { Maleylacetoacetate isomerase } \\
\text { Maleylacetoacetate isomerase } \\
\text { Glutathione S-transferase } \\
\text { Glutathione S-transferase } \\
\text { Glutathione S-transferase } \\
\text { Unknown } \\
\text { Glutathione S-transferase }\end{array}$ \\
\hline
\end{tabular}

4 Purine biosynthesis

\begin{tabular}{lc}
\multicolumn{1}{c}{ Organism } & Significance of similarity \\
Homo sapiens & $1.9 \mathrm{e}-121$ \\
Mus musculus & $6.7 \mathrm{e}-121$ \\
Aspergillus nidulans & $3.3 \mathrm{e}-119$ \\
Arabidopsis thaliana & $1.6 \mathrm{e}-24$ \\
Mycobacterium tuberculosis & $5.8 \mathrm{e}-7$ \\
Homo sapiens & $6.0 \mathrm{e}-36$ \\
Aspergillus nidulans & $8.7 \mathrm{e}-18$ \\
Homo sapiens & $5.4 \mathrm{e}-36$ \\
Caenorhabditis elegans & $1.7 \mathrm{e}-30$ \\
Dianthus caryophilus & $1.3 \mathrm{e}-12$ \\
Sphingomonas sp. & $2 \cdot 1 \mathrm{e}-33$ \\
Rhizobium leguminosarum & $2.8 \mathrm{e}-13$ \\
Rhodobacter capsulatus & $5.1 \mathrm{e}-15$
\end{tabular}

Fig. 4. Map of the $\mathrm{n} 4$ cluster, with indication of the Tn5/uxAB insertion site, ORFs, protein sequence similarities, organism with which similarity was found and similarity significance $(P$ value: probability that such a match would occur merely by chance, as given by the BLAST algorithm). P, Pstl; S, Sall; B, BamHI; E, ECoRI; X, Xhol.

out with cells grown on GTS medium, supplemented with different TY medium ingredients (Fig. 3b). Tyrosine, tryptophan and phenylalanine were tested at a concentration of $0.02 \%$, a typical concentration for TY medium. Only GTS supplemented with tyrosine caused the production of a significant level of luciferase activity in strain N4. GTS-N supplemented with tyrosine caused the production of a level of luciferase activity that was higher than with GTS-N or GTS + tyrosine. This suggests that more than one regulatory system may control the expression of the $\mathrm{n} 4$ locus. Supplementation of GTS-N with tryptophan did not influence the induction of the $\mathrm{n} 4$ gene fusion by the nitrogen- starvation condition. Phenylalanine, when added to GTS, did not cause induction of luciferase activity. However, GTS-N + phenylalanine caused a higher induction than GTS-N alone, indicating that phenylalanine stimulates expression of the $\mathrm{n} 4$ gene fusion only in nitrogen-free medium.

\section{DNA sequence analysis}

The DNA sequence of a $4 \mathrm{~kb}$ fragment harbouring the $\mathrm{n} 4$ locus was analysed. Several potential ORFs were identified, with the Tn5luxAB insertion located in ORF1 (see Fig. 4). A sequence similarity search in GenBank 
S.meliloti

H.sapiens

M.musculus

A.nidulans

S.meliloti

H.sapiens

M.musculus

A.nidulans

S.meliloti

H.sapiens

M.musculus

A.nidulans

S.meliloti

H.sapiens

M.musculus

A.nidulans

S.meliloti

H.sapiens

M.musculus

A.nidulans

S.meliloti

H.sapiens

M.musculus

A.nidulans

S.meliloti

H.sapiens

M.musculus

A.nidulans

S.meliloti

H.sapiens

M.musculus

A.nidulans

S.meliloti

H.sapiens

M.musculus

A.nidulans

S.meliloti

H.sapiens

M.musculus

A.nidulans
MLEKAEKQRRAGSG Q QRAAGMPG

-.........-. MAE L KY I S

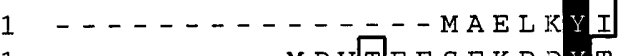

1

....... - M P V TEF S F K D PY

NE C A S
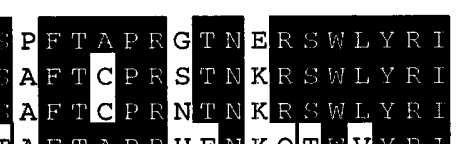

$\begin{array}{llll}\text { I } & \text { P S V V R } \\ \text { I L } & \text { P S V V S } \\ \text { I L P S V S }\end{array}$

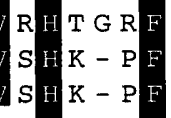

G R FR VDY P H W K TA P H G

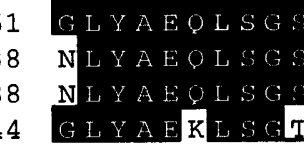

AFTAPR E N K
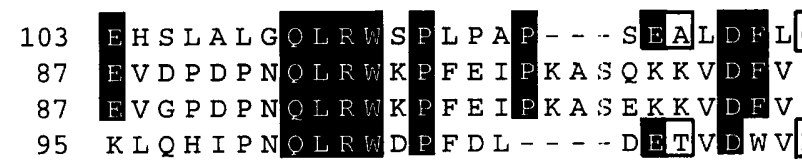

\begin{tabular}{l|l|l|l|l}
$\mathrm{L}$ & $\mathrm{O}$ \\
$\mathrm{VS}$ & $\mathrm{I}$ & $\mathrm{H}$ \\
$\mathrm{VSS}$ & $\mathrm{L}$ & $\mathrm{Y}$
\end{tabular}

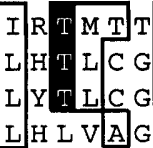

$-\mathrm{N} F$

- E S I D G H V T H N W D

- ESI DQ GHVTH N D

VEEDAS SYHTLS DAK

TAGDALTQA GAAHA Y A F DI K S N N G L A I H I F L C 138 95

152

139

139

143

204

191

191

195
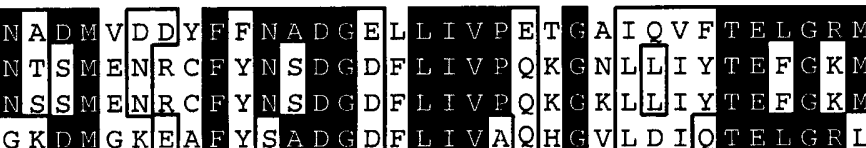

$\begin{array}{llllll}R & D & V & E & P & S \\ K & L & V & P & P & N \\ M & S & L & P & N\end{array}$

P TVK QGLG I L LYAA

138

142
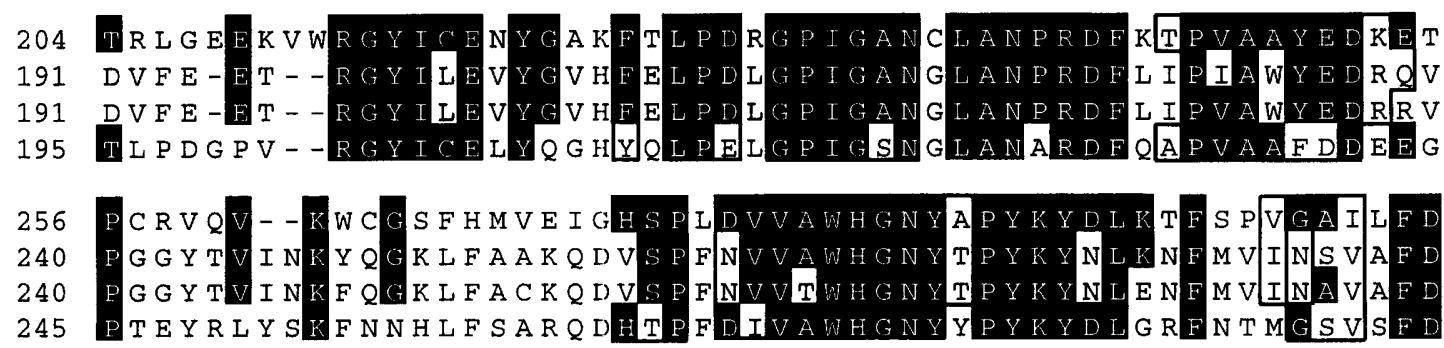
$D V F E-F T$

I P D P V -

PCRVQV--
PG Y TV I N K
P G GY TVINK
PTEYRLY SK

HPDPSIFTVLTAPS
HAD PSIFTVLTAK
HADPSIFTVLTAKS
HPDPSIVTVLTGPS
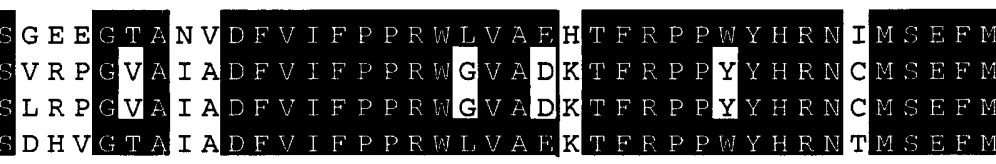

203

190

190

194

\section{8}

344

344

349
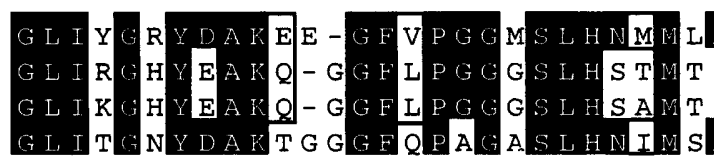

$I A H G A$
$T P H G P$
$T P H G P$
$S A H G P$

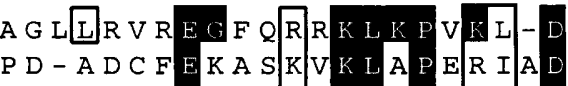

D-ADC FEKA SKa L L E ER I A D

255

239

239

244

\section{8}

394

394

400

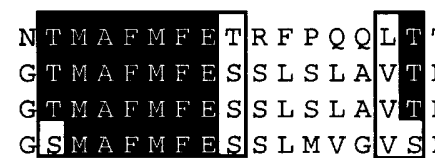

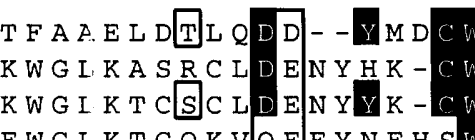

W

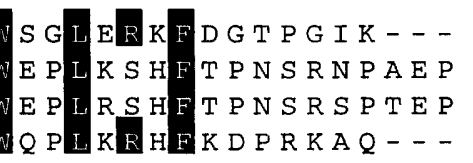

0

$445 \mathrm{~N}$

$445 \mathrm{~K}$

0 -
305

291

291

296

357

343

343

348

407

393

393

399

454

444

444

448

454

445

445

448

Fig. 5. Alignment of the $S$. meliloti $h m g A$ gene product with the deduced amino acid sequences of the $A$. nidulans $h m g A$ gene (accession no. U30797), the human ( $H$. sapiens) cDNA clone (U63008) and a mouse ( $M$. musculus) cDNA clone (U58988). These three eukaryotic loci encode homogentisate dioxygenase. Amino acids identical to those of $S$. meliloti are indicated in white on a black background; similar amino acids are boxed.

revealed a striking similarity of the deduced ORF1. product with eukaryotic enzymes, encoded by the $h m g A$ gene of Aspergillus nidulans (50\% identity, $56 \%$ simi. larity), a human cDNA clone $(50 \%$ identity, $57 \%$ similarity) and a cDNA clone of mouse $(51 \%$ identity, $57 \%$ similarity) (Fig. 5). All three loci encode homogentisate dioxygenase (hydroxyphenylacetate dioxy. genase), involved in the degradation of tyrosine (Fernandez-Canon \& Penalva, 1995; Fernandez-Canon et al., 1996; Schmidt et al., 1997). In humans, tyrosine degradation occurs through homogentisate, and interruptions of this pathway cause the disease alkaptonuria. Degradation of tyrosine has been studied to a much lesser extent in bacterial systems, such as Legionella 
S. meliloti maiA

H. sapiens maiA

A. nidulans maiA

$H$. sapiens gst

C. elegans gst

R. leguminosarum gst

S. meliloti maiA

H. sapiens maiA

A. nidulans maiA

H. sapiens gst

C. elegans gst

$R$. leguminosarum gst

S. meliloti maiA

$H$. sapiens maiA

A. nidulans maiA

$H$. sapiens gst

C. elegans gst

$R$. leguminosarum gst

S. meliloti maiA

H. sapiens maiA

A. nidulans maiA

H. sapiens gst

C. elegans gst

$R$. leguminosarum gst

S. meliloti maiA

H. sapiens maiA

A. nidulans maiA

H. sapiens gst

C. elegans gst

R. leguminosarum gst
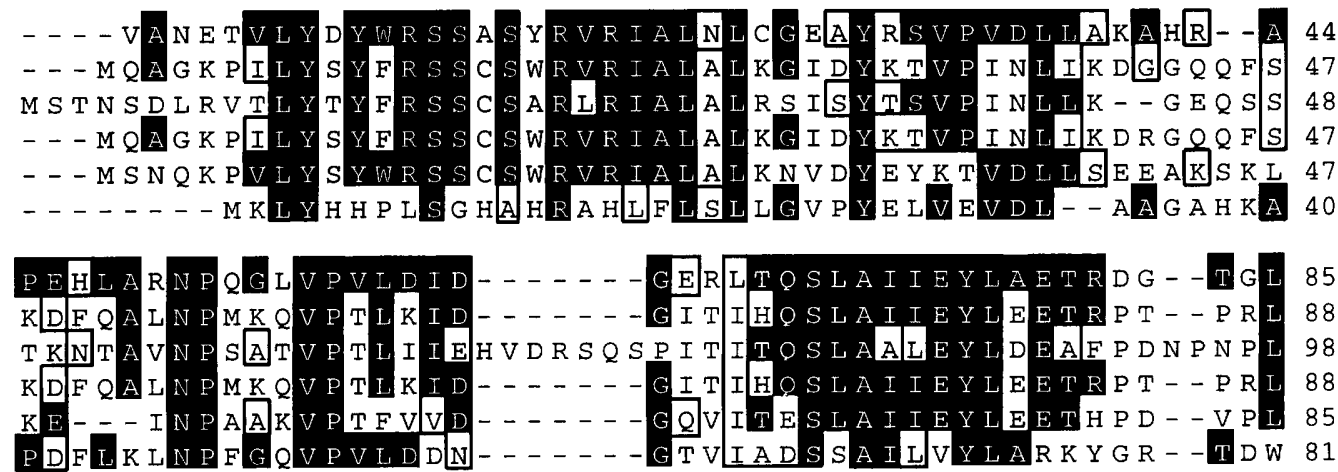
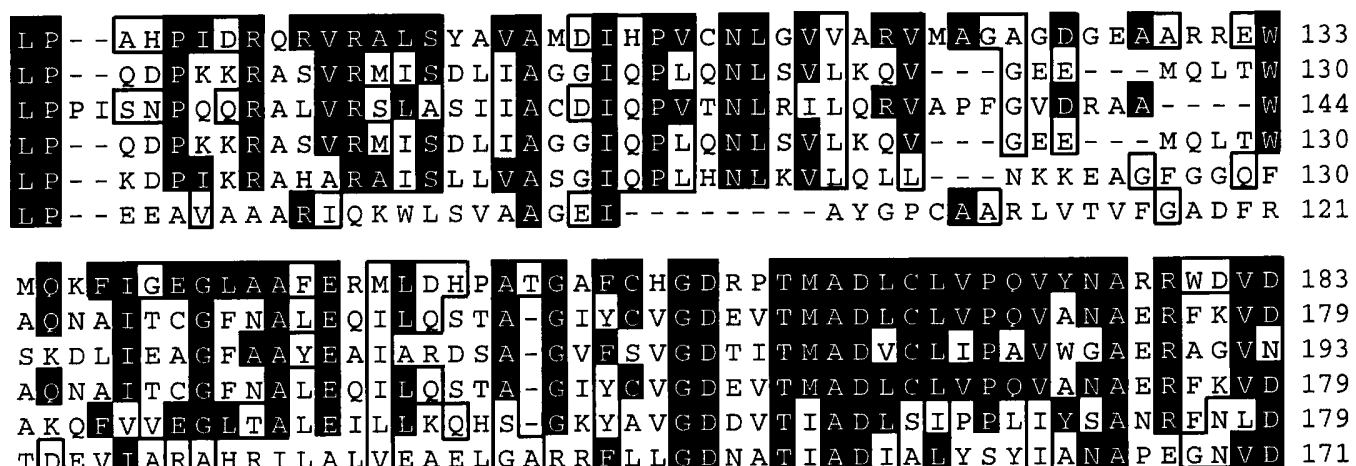

TDE V I A R A H R I L L V E A E L G A R R F L L

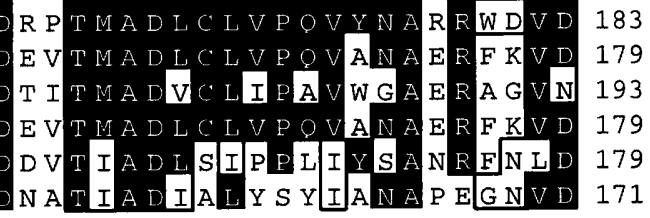

213

216

230

216

214

203

Fig. 6. Alignment of the S. meliloti maiA gene product with the deduced amino acid sequences of loci encoding maleylacetoacetate isomerase (accession nos AJ001838 and AJ001836) and GST (accession nos U86529, Z66560 and X89816). Amino acids identical to those of S. meliloti are indicated in white on a black background; similar amino acids are boxed.

pneumophila, Vibrio cholerae and Shewanella colwelliana (Steintert et al., 1995; Kotob et al., 1995; Coon et al., 1994). Two of the loci involved in the tyrosine degradation pathway have been identified and characterized: the melA and lly genes of $S$. colwelliana and L. pneumophila respectively (Fuqua et al., 1991; Wintermeyer et al., 1994). However, a $h m g A$-like gene such as the gene tagged with $\operatorname{Tn} 5 \operatorname{lu} x A B$ in strain N4 has not, to our knowledge, previously been described in bacteria.

Downstream from ORF1, we found three ORFs with the same transcriptional direction (Fig. 4). The deduced gene product of ORF2 displays a weak similarity with a protein encoded by an unknown ORF of $\mathrm{Myco-}$ bacterium tuberculosis (g1524223). The deduced amino acid sequence of ORF3, however, showed significant similarity with the recently described enzyme maleylacetoacetate isomerase, reported for A. nidulans and humans $(40 \%$ identity and $46 \%$ similarity; $47 \%$ identity and $54 \%$ similarity respectively) (Fig. 6 ; FernandezCanon \& Penalva, 1998). This enzyme is involved in the degradation of maleylacetoacetate, the next enzymic step in the tyrosine degradation pathway after the homogentisate dioxygenase step. Similarity of the deduced amino acid sequence encoded by ORF3 was also found with glutathione $S$-transferase (GST) from human (PID g2498441; $47 \%$ identity and 54\% similarity) and GST of the nematode Caenorhabditis elegans $(42 \%$ identity and $48 \%$ similarity; Wilson et al., 1998). Similarity was also found with the gene products encoded by a bacterial ORF with unknown function from Sphingomonas sp. (Armengaud \& Timmis, 1997) and the gstA gene of Rhizobium leguminosarum. The product of the latter gene, described as a GST based on sequence similarity, has not been ascribed a distinct function since a mutation in $g s t A$ does not display a distinct phenotype (Tawfiq Alkafaf et al., 1997). The $S$. meliloti ORF3 was followed by an ORF with significant similarity to the $3^{\prime}$ end of the gene product of a Rhodobacter capsulatus purU-like gene, possibly involved in purine biosynthesis (Armengaud et al., 1997).

The four S. meliloti ORFs are transcribed in the same 
Table 1. Growth of S. meliloti strains 1021 and N4 with different amino acids as nitrogen or carbon source

++ , Good growth; + , reduced growth; - , no growth.

\begin{tabular}{|lcc|}
\hline Medium & Strain 1021 & Strain N+ \\
\hline GTS & ++ & ++ \\
GTS-C & - & - \\
GTS-C + tyrosine & + & - \\
GTS-C + tryptophan & - & - \\
GTS-C + phenylalanine & - & - \\
GTS-N & - & - \\
GTS-N + tyrosine & + & + \\
GTS-N + tryptophan & + & + \\
GTS-N + phenylalanine & + & + \\
\hline
\end{tabular}

orientation and DNA sequence motifs characteristic of transcriptional terminators were not found in the intergenic regions. Thus the four ORFs may be part of the same transcriptional unit. Each of the four ORFs was preceded by a Shine-Dalgarno sequence. ORF 1 is $1359 \mathrm{bp}$ long, ORF 2 and ORF3 are 1174 and $639 \mathrm{bp}$ long, respectively. Upstream of ORF1, a $-35 /-10$ type of promoter consensus sequence was found. In addition, in the $5^{\prime}$ upstream region of ORF1, a small ORF with the opposite transcriptional direction was identified which may encode a regulator protein since amino acid sequence similarity searches, as well as a pattern search, revealed similarities with a group of bacterial regulatory proteins of the marR signature family (Prosite: PDOC00861; data not shown).

\section{Tyrosine as nitrogen and carbon source}

Since the $\mathrm{n} 4$ locus of $S$. meliloti was induced by nitrogen and carbon deprivation, as well as in the presence of tyrosine, we examined whether tyrosine could serve as sole carbon or nitrogen source for S. meliloti. Solid GTS medium, supplemented with tyrosine displayed a cloudy appearance due to partial precipitation of tyrosine. On this medium, a halo appeared around colonies of strains 1021 and N4, suggesting that tyrosine was metabolized by actively growing cells. Although the growth was slow, strain 1021 was found to be able to utilize tyrosine, tryptophan and phenylalanine as sole nitrogen sources but only tyrosine as sole carbon source (Table 1). Strain $\mathrm{N} 4$ was unable to grow on tyrosine as sole carbon source, indicating that the $\mathrm{n} 4$ locus is important for the derivation of carbon substrates from tyrosine; this is consistent with the observation that the $\mathrm{n} 4$ locus is induced under carbon-deprivation conditions. However, strain $\mathrm{N} 4$ was able to grow with tyrosine as sole nitrogen source, indicating that $S$. meliloti does not employ the entire degradation pathway to obtain nitrogen from tyrosine. Instead it may scavenge nitrogen from tyrosine at an earlier stage of the pathway, before the homogentisate dioxygenase catalysed step (see Fig.

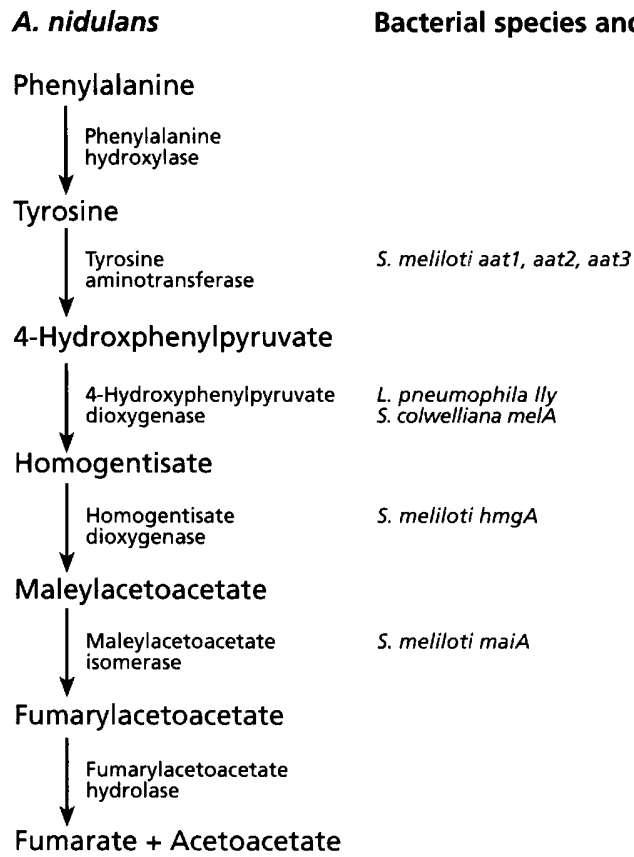

Fig. 7. Phenylalanine/tyrosine degradation pathway, described for $A$. nidulans. Bacterial genes, corresponding to the enzymes of this pathway, are indicated to the right.

7). Since the $n 4$ locus was induced by nitrogen deprivation, the induction of expression of the $\mathrm{n} 4$ gene fusion might be caused by degradation products of tyrosine. To support this conclusion, we tested two substrates of the tyrosine degradation pathway described for A. nidulans (homogentisate and hydroxyphenylpyruvic acid; Fernandez-Canon \& Penalva, 1995). As shown in Fig. 3(b), both these intermediates indeed induced the $\mathrm{n} 4$ gene fusion.

\section{Physiological and biochemical analysis of strain N4}

Strain N4 produced a brown pigment when grown in liquid or solid TY medium for several days. This was not observed for strain 1021. In regular GTS medium, pigmentation was not observed in exponentially growing cells, but older cultures, grown for at least $7 \mathrm{~d}$, did display a faint brown pigmentation. A similar observation has been reported for the $A$. nidulans mutant strain carrying an insertion in the $h m g A$ gene. The interruption of the $b m g A$ gene in this fungus results in the accumulation and secretion of homogentisate, which turns dark brown due to oxidation. Similarly, the pigment of strain $\mathrm{N} 4$ turned brown after prolonged incubation. The addition of tyrosine $(0.02 \%$ or $0.2 \%)$ to GTS medium enhanced the production of the pigment significantly at $0 \cdot 2 \%$. In aerated liquid medium, colour formation occurred much more quickly, with the cultures changing in a few days from a pale colour to pink, red, brown, and finally black. These data support the hypothesis that strain $\mathrm{N} 4$ is secreting homogentisate. 


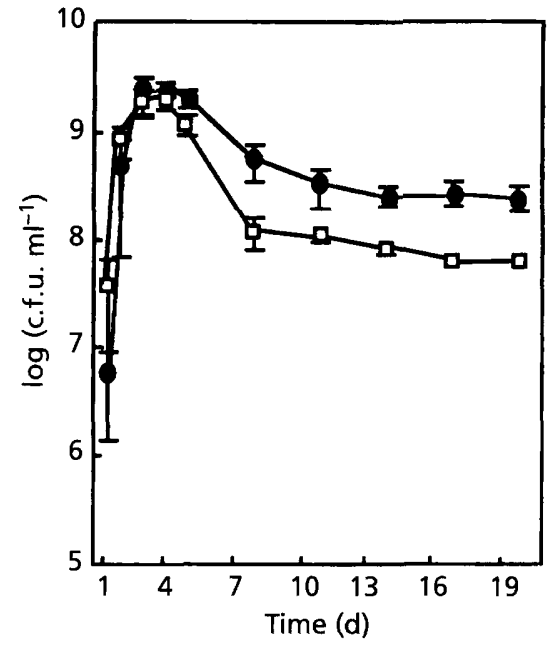

Fig. 8. Growth and survival of strains N4 ( $\square$ ) and 1021 (๑) in liquid minimal GTS medium. The results are means of three measurements from three cultures, \pm SE.

Additional evidence for the proposed interruption of the tyrosine degradation pathway in strain $\mathrm{N4}$, and the block in homogentisate dioxygenase activity, was obtained by enzyme assays. Cell extracts of strains 1021 and N4 were spectrophotometrically analysed for the presence of maleylacetoacetate, the degradation product of homogentisate (see Methods). Cell extracts of strain 1021 but not of strain $\mathrm{N} 4$, showed absorption at $A_{330}$, suggesting that the mutant strain $\mathrm{N} 4$ cannot produce maleylacetoacetate.

\section{Growth rate and survival of strain N4}

The growth rate and survival characteristics of strains $\mathrm{N} 4$ and 1021 in stationary growth phase was analysed. Both strains were individually grown in minimal GTS medium and colony-forming units were determined at regular intervals for up to 3 weeks. Strain N4 was found to be unaffected in growth rate, but in the stationary growth phase a decrease in viable counts was observed (Fig. 8). This decline in survival might be due to the transposon insertion in strain $\mathrm{N} 4$, rendering the strain incapable of scavenging carbon from tyrosine, which may constitute an alternative nutrient source in starving, stationary-phase cells. Reduction of survival, observed after 1 week of growth, was found to occur concomitantly with the production of the light brown pigment, resulting from homogentisate secretion. Examination of strains 1021 and N4 for growth in minimal GTS medium supplemented with homogentisate at different concentrations $(0 \cdot 0001-0.02 \%)$, showed that this substrate prevented growth at a concentration of $0.01 \%$ or higher. Smaller concentrations of homogentisate allowed growth but at a reduced rate, suggesting that homogentisate has a toxic effect on $S$. meliloti cells. Therefore, the observed impairment of survival of strain N4 in minimal GTS medium may be the result of the inability to use tyrosine as nutrient source or the secretion of the toxic compound homogentisate.

\section{Symbiotic phenotype of strain N4 on alfalfa plants}

Alfalfa plants inoculated with strain N4 displayed a normal nodulation and growth phenotype. Nodules were produced that were regular in shape, colour and number, and the nodules displayed acetylene reduction activity similar to those produced by inoculation with strain 1021 (data not shown); this suggests that the tyrosine catabolism pathway via homogentisate dioxygenase is not essential for nodulation and symbiotic nitrogen fixation.

\section{DISCUSSION}

In a recent study (Milcamps et al., 1998), we reported that under nutrient-deprivation conditions, $S$. meliloti induces several genes responsible for scavenging nitrogen/carbon from alternative nutrient sources such as amino acids, nitrate, ribose, etc. Out of a collection of 21 strains harbouring nitrogen-deprivation-induced $\operatorname{lu} x A B$ fusions, strain $\mathrm{N} 4$ was selected and subsequently shown to be induced by both nitrogen- and carbondeprivation conditions. In addition, supplementation of the growth medium with tyrosine was found to induce the $\mathrm{n} 4$ gene fusion. These results suggest that a complex regulatory system responding to distinct environmental cues may be controlling the expression of the $n 4$ locus. In this paper, we present the results of biochemical and molecular studies showing that the $S$. meliloti n4 locus contains a gene encoding the enzyme homogentisate dioxygenase, which is responsible for the conversion of homogentisate to maleylacetoacetate. Given the highly significant similarities of the Tn5luxAB-tagged gene in $S$. meliloti strain N4 with genes encoding homogentisate dioxygenase in A. nidulans, human and mouse, as well as the similarity in phenotype of strain $\mathrm{N} 4$ with the $A$. nidulans mutant strain in terms of production of a brown pigment and the capacity to use tyrosine as nutrient source, we propose to name ORF1 in the $S$. meliloti 4 locus hmgA. We believe that this constitutes the first report of the identification of a gene encoding homogentisate dioxygenase in bacteria.

Downstream of the $S$. meliloti bmgA gene we found an ORF with significant similarity to eukaryotic genes encoding maleylacetoacetate isomerase (maiA) and GST $(g s t)$. Maleylacetoacetate isomerase functions in the tyrosine degradation pathway of $A$. nidulans and humans, and catalyses the step after the homogentisate dioxygenase step. The $A$. nidulans gene maiA is clustered with the $h m g A$ gene. In $S$. meliloti, the $h m g A$ gene and the putative maiA gene may constitute a single transcriptional unit, suggesting their involvement in the same catabolic pathway. Similarity was also discovered with several GSTs. In eukaryotes, the GSTs constitute a large supergene family of detoxifying enzymes which function 
by conjugation of the tripeptide glutathione to electrophilic substrates (Meister \& Anderson, 1983). Data for prokaryotes are not abundant, but several studies on microbes have shown that GSTs may have a role in detoxification of xenobiotics (Zablotowicz et al., 1995; Lloyd-Jones \& Lau, 1997; Vuilleumier, 1997). Moreover, some GST enzymes have been reported to function as isomerases using maleylacetoacetate as substrate, which explains their amino acid similarity with the maleylacetoacetate isomerases (Seltzer, 1989).

It is intriguing that both the $S$. meliloti $h m g A$ gene and the putative maiA gene share very high similarities with eukaryotic genes. Although several bacterial genomes have been sequenced, we did not find high similarities with bacterial genes.

In contrast to amino acid synthesis, little is known about degradation of amino acids, such as tyrosine, in bacteria. The major pathway for tyrosine catabolism in mammals, humans and fungi has been shown to involve homogentisate as a key intermediate (Fernandez-Canon \& Penalva, 1995; Fernandez-Canon et al., 1996). Phenylalanine is converted to tyrosine and subsequently degraded to homogentisate. The aromatic ring of homogentisate is cleaved by the enzyme homogentisate dioxygenase and after isomerization to fumarylacetoacetate, fumarate and acetoacetate are produced (see Fig. 7). Micro-organisms appear to possess a similar pathway, and evidence for tyrosine degradation via this pathway derives from studies on microbial growth on medium containing tyrosine and identification of homogentisate as intermediate; the ability of cells to metabolize homogentisate and hydroxyphenylpyruvate; and the detection of homogentisate dioxygenase activity in microbial cells (Blackley, 1977). Only recently have genes encoding enzymes in this pathway been identified. In the case of $A$. nidulans, several genes of the tyrosine degradation pathway have been isolated, including $f a h A$, encoding fumarylacetoacetate hydrolase, $h m g A$, encoding homogentisate dioxygenase, and maiA, encoding maleylacetoacetate isomerase (FernandezCanon \& Penalva, 1995, 1998). In bacteria, only the melA and lly genes of S. colwelliana and L. pneumophila, encoding hydroxyphenylpyruvate dioxygenase, which converts hydroxyphenylpyruvate to homogentisate, have been described (Fuqua et al., 1991; Wintermeyer et al., 1994).

Tyrosine was found to serve as a nitrogen source as well as a carbon source for $S$. meliloti. Tyrosine is catabolized via a series of enzymic steps, yielding succinate and fumarate, which enter the Krebs cycle and provide the cell with energy and substrates. When tyrosine is used as nitrogen source, nitrogen is obtained via deamination of the amino group of tyrosine. Three $S$. meliloti genes have been described which are involved in the deamination of aromatic amino acids, such as tyrosine (Kittell et al., 1989). Deamination makes nitrogen available in the first step of tyrosine degradation, well before the step involving homogentisate dioxygenase (see Fig. 7). This is consistent with the observation that strain $\mathrm{N} 4$ is not impaired in growth on tyrosine as nitrogen source. Interestingly, the $b m g A$ gene is induced under nitrogen-deprivation conditions. This induction may be due to tyrosine itself or degradation products of the tyrosine pathway since homogentisate and hydroxyphenylpyruvic acid, two intermediates in the tyrosine degradation pathway (see Fig. 7), were also found to induce luciferase expression in strain N4.

Phenylalanine served as a nitrogen source but not as a carbon source. Also, the n4 locus was found to be induced by phenylalanine, but only under nitrogen starvation conditions. This observation suggests that phenylalanine may be converted to tyrosine only when nitrogen is limiting. As only limited information on bacterial degradation of amino acids is available, we do not know the mechanism which bacteria employ to degrade phenylalanine. Our observations suggest that bacteria, in contrast to fungi, may have other pathways and other regulatory conditions to degrade phenylalanine.

Another interesting observation from this study was the production of a brown pigment by strain $\mathrm{N} 4$, as a result of homogentisate secretion. Brown pigments derived from homogentisate are described as melanin-type pigments (pyo-melanin) (Yabuuchi \& Ohyama, 1972). Melanin production in $S$. meliloti strain 1021 is not a naturally occurring process, but has been observed in other bacteria such as Vibrio cholerae, S. colwelliana and L. pneumophila (Coyne \& Al-Harthi, 1992; Fuqua et al., 1991; Wintermeyer et al., 1994), as well as in other Rhizobium strains (Cubo et al., 1988). Several different pathways have been described for melanin production (via DOPA, or homogentisate, or catechol) but few genetic studies have been carried out to support the biochemical data. The most common pathway for melanin production in rhizobia is via DOPA $(3,4-$ dihydroxyphenylalanine), which can be easily detected with tyrosine and $\mathrm{CuSO}_{4}$ in the medium (Cubo et al., 1988). In the case of strain N4, the brown pigmentation appears to be the result of the accumulation of homogentisate in the medium and subsequent oxidation and polymerization, which results in the formation of pyomelanin. The fungus $A$. nidulans, with a mutation in the $b m g A$ gene, displays a similar phenotype (Fernandez-Canon \& Penalva, 1995); and in humans, disruption of homogentisate dioxygenase results in the excretion of melanin in urine (Fernandez-Canon et al., 1996).

From our phenotypic analysis, we conclude that the $S$. meliloti 4 locus is important for survival. Although the interruption of the locus is not lethal for the cell, the mutation has an effect upon the ability to grow with tyrosine as carbon source which might be important for survival, as was deduced from the reduced viability of strain $\mathrm{N} 4$ in the stationary growth phase. In addition, the secretion of homogentisate, due to the interruption of the $h m g A$ gene, seems to have a negative effect upon survival. The exact role of the $\mathrm{n} 4$ locus in the starvation response, persistence and survival of $S$. meliloti in the soil or rhizosphere is being further investigated. 


\section{ACKNOWLEDGEMENTS}

This work was supported by NSF STC grant no. DEB9120006 from the Center of Microbial Ecology, NSF grant no. IBN9402659 from the National Science Foundation and grant no. DE-FG02-91ER20021 from the Department of Energy. Dr Anne Milcamps is the recipient of a Collen Foundation Fellowship. We would like to thank Dr Peter Wolk and Dr Mike Tomashow for the use of the photonic camera and the luminometer, as well as helpful discussions.

\section{REFERENCES}

Alexander, D. M. \& St John, A. C. (1994). Characterization of the carbon starvation-inducible and stationary phase-inducible gene slp encoding an outer membrane lipoprotein in Escherichia coli. Mol Microbiol 11, 1059-1071.

Alexander, D. M., Damerau, K. \& St John, A. C. (1993). Carbohydrate uptake genes in Escherichia coli are induced by carbon starvation. Curr Microbiol 27, 335-340.

Altschul, S. F., Gish, W., Miller, W., Myers, E. W. \& Lipman, D. J. (1990). Basic local alignment search tool. J Mol Biol 215, 403-410.

Armengaud, J. \& Timmis, K. N. (1997). Molecular characterization of $\mathrm{Fdx} 1$, a putida-redoxin type [2Fe-2S] ferredoxin able to transfer electrons to the dioxin dioxygenase of Sphingomonas sp. RW1. Eur J Biochem 247, 833-842.

Armengaud, J., Meyer, C. \& Jouanneau, Y. (1997). A $2 \mathrm{Fe}-2 \mathrm{~S}$ ferredoxin (FdVI) is essential for growth of the photosynthetic bacterium Rhodobacter capsulatus. J Bacteriol 179, 3304-3309.

Atlung, T., Knudsen, K., Heerfort, L. \& Bronsted, L. (1997). Effects of sigma $S$ and the transcriptional activator AppY on induction of the Escherichia coli hya and $c b d A B-a p p A$ operons in response to carbon and phosphate starvation. J Bacteriol 179, 2141-2146.

Beringer, J. E. (1974). $\mathrm{R}$ factor transfer in Rhizobium leguminosarum. J Gen Microbiol 84, 188-198.

Blackley, E. R. (1977). The catabolism of L-tyrosine by an Arthrobacter sp.: changes in macromolecular synthesis during entry to and exit from stationary phase. Can J Microbiol 23, $1128-1139$.

Broughton, W. J. \& Dilworth, M. J. (1971). Control of leghaemoglobin synthesis in snake beans. Biochem $J \mathbf{1 2 5}$, $1075-1080$

de Bruijn, F. J. \& Rossbach, S. (1994). Transposon mutagenesis. In Methods for General and Molecular Biology, pp. 387-504. Edited by P. Gerhardt, R. G. E. Murray, W. A. Wood \& N. R. Krieg. Washington, DC: American Society for Microbiology.

Coon, S. L., Kotob, S., Jarvis, B. B., Wang, S., Fuqua, W. C. \& Weiner, R. M. (1994). Homogentisic acid is the product of melA, which mediates melanogenesis in the marine bacterium Shewanella colwelliana D. Appl Environ Microbiol 60, 3006-3010.

Coyne, V. E. \& Al-Harthi, L. (1992). Induction of melanin biosynthesis in Vibrio cholerae. Appl Environ Microbiol 58, $2861-2865$

Cubo, M. T., Buendia-Claveria, A. M., Beringer, J. E. \& Ruiz-Sainz, J. (1988). Melanin production by Rhizobium strains. Appl Environ Microbiol 54, 1812-1817.

Ditta, G., Stanfield, S., Corbin, D. \& Helinski, D. R. (1980). Broad host range DNA cloning system for Gram-negative bacteria: construction of a gene bank of Rhizobium meliloti. Proc Natl Acad Sci USA 77, 7347-7351.

Edwards, S. M. \& Knox, W. E. (1955). Preparation and assay of enzymes. Methods Enzymol 2, 292-295. van Elsas, J. D. \& van Overbeek, L. S. (1993). Bacterial responses to soil stimuli. In Starvation in Bacteria, pp. 55-77. Edited by S. Kjelleberg. New York: Plenum.

Fernandez-Canon, J. \& Penalva, M. A. (1995). Molecular characterization of a gene encoding a homogentisate dioxygenase from Aspergillus nidulans and identification of its human and plant homologues. J Biol Chem 270, 21199-21205.

Fernandez-Canon, J. \& Penalva, M. A. (1998). Characterization of a fungal maleylacetoacetate isomerase gene and identification of its human homologue. J Biol Chem 273, 329-337.

Fernandez-Canon, J. M., Granadino, B., Beltran-Valero de Bernabe, D., Renedo, M., Fernandez-Ruiz, E., Penalva, M. A. \& de Cordoba, R. (1996). The molecular basis of alkaptonuria. Nat Genet 14, 19-24.

Foster, J. W. \& Spector, M. P. (1995). How Salmonella survive against the odds. Annu Rev Microbiol 49, 145-174.

Friedman, A. M., Long, S. R., Brown, S. E., Buikema, W. I. \& Ausubel, F. M. (1982). Construction of a broad host range cosmid cloning vector and its use in the genetic analysis of Rhizobium mutants. Gene 18, 289-296.

Fuqua, C., Coyne, V. E., Stein, D. C., Lin, C. M. \& Weiner, R. M. (1991). Characterization of melA: a gene encoding melanin biosynthesis from the marine bacterium Shewanella colwelliana. Gene 109, 131-136.

Graham, P. H. (1991). Stress tolerance in Rhizobium and Bradyrhizobium, and nodulation under adverse soil conditions. Can J Microbiol 38, 475-484.

Hanahan, D. (1983). Studies on transformation of Escherichia coli with plasmids. $J \mathrm{Mol}$ Biol 166, 557-580.

Hecker, M., Schumann, W. \& Volker, U. (1996). Heat-shock and general stress response in Bacillus subtilis. Mol Microbiol 19, 417-428.

Hengge-Aronis, R. (1993). Survival of hunger and stress: the role of $r p o S$ in early stationary phase gene regulation in Escherichia coli. Cell 72, 165-168.

Hirsch, P. R. \& Beringer, J. E. (1984). A physical map of pPHIJI and pJB41. Plasmid 12, 139-141.

Kasahara, M., Makino, K., Amemura, M., Nakata, A. \& Shinagawa, H. (1991). Dual regulation of the $u g p$ operon by phosphate and carbon starvation at two interspaced promoters. J Bacteriol 172, 549-558.

Kim, Y., Watrud, L. S. \& Matin, A. (1995). A carbon starvation survival gene of Pseudomonas putida is regulated by sigma 54 . J Bacteriol 177, 1850-1859.

Kiss, G. B., Vincze, E., Kalman, Z., Forrai, T. \& Kondorosi, A. (1979). Genetic and biochemical analysis of mutants affected in nitrate reduction in Rbizobium meliloti. J Gen Microbiol 113, 105-118.

Kittell, B. L., Helinski, D. R. \& Ditta, G. S. (1989). Aromatic aminotransferase activity and indoleacetic acid production in Rhizobium meliloti. J Bacteriol 171, 5458-5466.

Kolter, R., Siegele, D. A. \& Torma, A. (1993). The stationary phase of the bacterial life cycle. Annu Rev Microbiol 47, 855-874.

Kotob, S. I., Coon, S. L., Quintero, E. J. \& Weiner, R. M. (1995). Homogentisic acid is the primary precursor of melanin synthesis in Vibrio cholerae, a Hyphomonas strain, and Shewanella colwelliana. Appl Environ Microbiol 61, 1620-1622.

Kragelund, L., Christoffersen, B., Nybroe, O. \& de Bruijn, F. J. (1995). Isolation of lux reporter gene fusions in Pseudomonas fluorescens DF57 inducible by nitrogen or phosphorus starvation. FEMS Microbiol Ecol 17, 25-49. 
Kragelund, L., Hosbond, C. \& Nybroe, O. (1997). Distribution of metabolic activity and phosphate starvation response of luxtagged Psendomonas fluorescens reporter bacteria in the barley rhizosphere. Appl Environ Microbiol 63, 4920-4928.

Lange, L. N. \& Hengge-Aronis, R. (1991). Growth phase regulated expression of bolA and morphology of stationary-phase Escherichia coli cells are controlled by the novel sigma factor $\sigma^{s}$. $J$ Bacteriol 173, 4474-4481.

Lange, L. N. \& Hengge-Aronis, R. (1991). Identification of a central regulator of stationary-phase gene expression in Escherichia coli. Mol Microbiol 5, 49-59.

Li, C., Ichikawa, J. K., Ravetto, J. J., Kuo, H. C., Fu, J. C. \& Clarke, S. (1994). A new gene involved in stationary-phase surviva located at 59 minutes on the Escherichia coli chromosome J Bacteriol 176, 6015-6022.

Lloyd-Jones, G. \& Lau, P. C. K. (1997). Glutathione-S-transferase encoding gene as a potential probe for environmental bacterial isolates capable of degrading polycyclic aromatic hydrocarbons. Appl Environ Microbiol 63, 3286-3290.

Lomovskaya, O. L., Kidwell, J. P. \& Matin, A. (1994). Characterization of the sigma 38 dependent expression of a core Escherichia coli starvation gene, pexB. J Bacteriol 176, 3928-3935.

Lynch, J. M. \& Whipps, J.M. (1990). Substrate flow in the rhizosphere. Plant Soil 129, 1-10.

Mandelstam, J. (1963). Protein turnover and its function in the economy of the cell. Ann N Y Acad Sci 102, 621-636.

Matin, A. (1991). The molecular basis of carbon-starvationinduced general resistance in Escherichia coli. Mol Microbiol 5, 3-10.

Matin, A., Auger, E. A., Blum, P. H. \& Schultz, J. E. (1989). Genetic basis of starvation survival in nondifferentiating bacteria. Annu Rev Microbiol 43, 293-316.

Meade, H. M., Long, S. R., Ruvkun, G. B., Brown, S. E. \& Ausubel, F. M. (1982). Physical and genetic characterization of symbiotic and auxotrophic mutants of Rhizobium meliloti induced by transposon Tn5 mutagenesis. J Bacteriol 149, 114-122.

Meighen, E. A. \& Dunlap, P. V. (1993). Physiological, biochemical and genetic control of bacterial bioluminescence. Adv Microb Physiol 34, 1-67.

Meister, A. \& Anderson, M. E. (1983). Glutathione. Annu Rev Biochem 52, 711-760.

Milcamps, A., Ragatz, D. M., Lim, P., Berger, K. A. \& de Bruijn, F. J. (1998). Isolation of carbon- and nitrogen-deprivationinduced loci of Sinorhizobium meliloti by Tn5-luxAB mutagenesis. Microbiology 144, 3205-3218.

Moriarty, D. J. W. \& Bell, R. T. (1993). Bacterial growth and starvation in aquatic environments. In Starvation in Bacteria, pp. 25-48. Edited by S. Kjelleberg. New York \& London: Plenum.

Nystrom, T. (1994). The glucose-starvation stimulon of Escherichia coli: induced and repressed synthesis of enzymes of central metabolic pathways and role of acetyl phosphate in gene expression and starvation survival. Mol Microbiol 12, 833-843.

Nystrom, T. (1995). Glucose starvation stimulon of Escherichia coli: role of integration host factor in starvation survival and growth phase-dependent protein synthesis. J Bacteriol 177, 5707-5710.

Nystrom, T. \& Neidhart, F. C. (1994). Expression and role of the universal stress protein, UspA, of Escherichia coli during growth arrest. Mol Microbiol 11, 537-544.

Okita, T. W., Rodriquez, R. L. \& Preiss, J. (1981). Biosynthesis of bacterial glycogen: cloning of the glycogen biosynthetic enzyme structural genes of Escherichia coli. J Biol Chem 256, 6944-6952.

Ostling, J., Holmquist, L., Flardh, K., Svenblad, B., Jouper-Jaan, A. \& Kjelleberg, S. (1993). Starvation and recovery of Vibrio. In Starvation in Bacteria, pp. 103-123. Edited by S. Kjelleberg. New York \& London: Plenum.

Roszak, D. B. \& Colwell, R. R. (1987). Survival strategies of bacteria in the natural environment. Microbiol Rev 51, 365-379.

Ruvkun, G. B. \& Ausubel, F. M. (1981). A general method for sitedirected mutagenesis in prokaryotes. Nature 289, 85-88.

Sambrook, J., Fritsch, E. F. \& Maniatis, T. (1989). Molecular Cloning: a Laboratory Manual, 2nd edn. Cold Spring Harbor, NY: Cold Spring Harbor Laboratory.

Schmidt, S. R., Gehrig, A., Koehler, M. R., Schmidt, M., Mueller, C. R. \& Kress, W. (1997). Cloning of the homogentisate dioxygenase gene, the key enzyme of alkaptonuria in mouse. Mamm Genome 8, 168-171.

Schultz, J. E. \& Matin, A. (1991). Molecular and functional characterization of a carbon starvation gene of Escherichia coli. J Mol Biol 218, 129-140.

Seltzer, S. (1989). Maleylacetoacetate cis-trans isomerase. In Glutathione: Chemical, Biochemical and Medical Aspects, pp. 733-751. Edited by D. Dolphin, O. Avramovic \& R. Poulson. New York: Wiley-Interscience.

Siegele, D. A. \& Kolter, R. (1992). Life after log. J Bacteriol 174, 345-348.

Silhavy, T. J., Berman, M. L. \& Enquist, L. W. (1984). Experiments with Gene Fusions. Cold Spring Harbor, NY: Cold Spring Harbor Laboratory.

Spector, M. P. \& Foster, J. W. (1993). Starvation stress response of Salmonella typhimurium: gene expression and survival during nutrient starvation. In Starvation in Bacteria, pp. 201-221. Edited by S. Kjelleberg. New York \& London: Plenum.

Steintert, M., Englehard, H., Flugel, M., Wintermeyer, E. \& Hacker, J. (1995). The Lly protein protects Legionella pneumophila from light but does not directly influence its intracellular survival in Hartmanella vermiformis. Appl Environ Microbiol 61, 2428-2430.

Tawfiq Alkafaf, N. K., Yeoman, K. H., Wexler, M., Hussain, H. \& Johnston, A.W. B. (1997). Analysis of a Rhizobium leguminosarum gene encoding a protein homologous to glutathione-S-transferase. Microbiology 143, 813-822.

Thorne, S. H. \& Williams, H. D. (1997). Adaptation of nutrient starvation in Rhizobium leguminosarum bv. phaseoli: analysis of survival, stress resistance, and changes in macromolecular synthesis during entry to and exit from stationary phase. J Bacteriol 179, 6894-6901.

Uhde, C., Schmidt, R., Jording, D., Selbitschka, W. \& Puhler, A. (1997). Stationary-phase mutants of Sinorhizobium meliloti are impaired in stationary-phase survival or in recovery to logarithmic growth. J Bacteriol 179, 6432-6440.

Vuilleumier, S. (1997). Bacterial glutathione- $S$-transferases: what are they good for? J Bacteriol 179, 1431-1441.

Weichart, D., Lange, R., Henneberg, N. \& Hengge-Aronis, R. (1993). Identification and characterization of stationary phaseinducible genes in Escherichia coli. Mol Microbiol 10, 407-420.

Williams, S. T. (1985). Oligotrophy in soil: fact or fiction? In Bacteria in the Natural Environment: the Effect of Nutrient Conditions, pp. 81-100. Edited by M. Fletcher \& G. Floodgate. New York: Academic Press. 
Williams, M. D., Ouyang, T. X. \& Flickinger, M. C. (1994). Starvation-induced expression of SspA and SspB: the effects of a null mutation in $s s p A$ on Escherichia coli protein synthesis and survival during growth and prolonged starvation. Mol Microbiol 11, 1029-1043.

Wilson, R. and 54 other authors (1998). $2 \cdot 2 \mathrm{Mb}$ of contiguous nucleotide sequence from chromosome III of C. elegans. Nature 368, 32-38.

Wintermeyer, E., Flugel, M., Ott, M., Steintert, M., Rdest, U., Mann, K. H. \& Hacker, J. (1994). Sequence determination and mutational analysis of the lly locus of Legionella pneumophila. Infect Immun 3, 1109-1117.

Wolk, P. C., Cai, Y. \& Panoff, J. M. (1991). Use of a transposon with luciferase as a reporter to identify environmentally responsive genes in a cyanobacterium. Proc Natl Acad Sci USA 88, 5355-5359.

Yabuuchi, E. \& Ohyama, A. (1972). Characterization of 'pyomelanin'-producing strains of Pseudomonas aeruginosa. Int J Syst Bacteriol 22, 53-64.

Yamanaka, K. \& Inouye, M. (1997). Growth-phase dependent expression of $c s p D$, encoding a member of the $c s p A$ family in Escherichia coli. J Bacteriol 179, 5126-5130.

Yamashino, T., Kadeda, M., Ueguchi, C. \& Mizuno, T. (1994). An analogue of the DnaJ molecular chaperone whose expression is controlled by sigma S during the stationary phase and phosphate starvation in Escherichia coli. Mol Microbiol 13, 475-483.

Zablotowicz, R. M., Hoagland, R. E., Locke, M. A. \& Hickey, W. J. (1995). Glutathione-S-transferase activity and metabolism of glutathione conjugates by rhizosphere bacteria. Appl Environ Microbiol 61, 1054-1060.

Received 3 August 1998; revised 18 December 1998; accepted 13 January 1999. 